\title{
Strategic Management Tools for Innovative Development of the Region
}

\author{
NATALIIA KRASNOSTANOVA ${ }^{1}$, INNA YATSKEVYCH ${ }^{2}$, SERHII MAIDANIUK ${ }^{3}$, \\ VOLODYMYR PALAMARCHUK ${ }^{4}$, NATALIIA PRYVALOVA ${ }^{5}$ \\ 1,2,3,4,5 Department of Management Organizations, ODESSA REGIONAL INSTITUTE FOR PUBLIC ADMINISTRATION, \\ NATIONAL ACADEMY FOR PUBLIC ADMINISTRATION UNDER THE PRESIDENT OF UKRAINE, UKRAINE. \\ E-mail: krasnostanova5906@murdoch.in
}

\begin{abstract}
The relevance of the problem under study is due to the fact that at present the dependence of countries and regions on the world economy is increasing, there is a transition to an information society and a knowledge economy, there are changes in the way of life of people, which requires the use of new approaches to managing the development of regions and ensuring their competitiveness. The main priority task of the regional policy aimed at increasing the competitiveness of regions should be the development of their scientific, technological and innovative potential. To do this, it is necessary to find and effectively use tools for the strategic management of innovative development of regions. The purpose of the article is to develop recommendations for managing the innovative development of the region. The leading approach to problem research. The main research methods used within the framework of the article: analysis and synthesis of theoretical and legal materials, statistical analysis of data (indicators of dynamics, structure, incl.). Statistical indicators reflecting the innovative development of the region and other regions directly located in the south of Ukraine in the Black Sea region are considered. The article discusses the concepts of "strategic management", "innovative development of the region". Also, the tools of strategic management of innovative development at the regional level were considered, statistical indicators characterising the innovative development of the Odesa region were evaluated. Based on the results of the analysis, the problems of innovative development have been identified and ways to solve them have been developed. The transition of the Ukrainian economy to an innovative path of development requires from the regions special attention to the search and use of internal development reserves, based on the available scientific and intellectual potential. The existing approaches to the effectiveness of the instruments of state strategic management of the innovative development of the country's regions require revision. The priority ways of improving the management tools for regional innovative development are: the development of public consciousness, innovation and entrepreneurial culture; motivation of the population and entrepreneurship to actively innovate; improving the content of specialised training of management personnel for innovative development; algorithmicising the activities of regional leaders in managing regional innovative development. The implementation of the listed areas will contribute to innovative development, an increase in the efficiency of the regional economy, and an increase in the standard of living of the population. Practical significance: The materials of the article are of practical value for improving the strategic management of the innovative development of the region.
\end{abstract}

Keywords: innovation, innovation activity, innovative development, research and development, region, strategic management

JEL Classification: 018, O32, P48 


\section{Introduction}

The level of socio-economic development of the country and its place in the modern world are largely determined by the possibilities of innovative development of the regions, based on scientific, intellectual and innovative potential. World practice shows that the level of innovative development of the country as a whole is largely determined by the intensity of innovative processes at the regional level. For Ukraine, with its large territory and differences in socio-economic development, the regional aspects of science, technology and innovation policy are of significant importance (Gurieva et al., 2019; Gurianov, 2015). Despite the understanding at all levels of management of the importance of the innovative path of development, there are still no effective mechanisms of state or regional support for innovation in Ukraine, and the practice of enterprises indicates a number of problems in this area and low innovation activity, which does not contribute to increasing the competitiveness of regions. At the same time, global financial and economic influences, territorial competition for resources and their limitations have shown the relevance of the innovative development of regions, which, in turn, requires the use of tools and methods adequate to modern social and economic trends. Innovations should be considered as a resource for increasing the competitiveness of products of individual enterprises, industries and industry as a whole, not only in the domestic market but also in the international one. The process of dissemination of innovations should move from centralised to local, when individual regions, thanks to local innovation processes, will become "points of innovative growth" of the national economy (Shelygov et al., 2019; Bobrova et al., 2020).

As practice shows, innovative development depends on the implementation of management strategies. The implementation of any strategy requires certain changes, and the introduction of changes faces resistance and numerous problems and obstacles. The art of strategists lies not only in formulating a good strategy but also in successfully managing the process of strategic change and development. The outdated sectoral structure of production (small high-tech potential), low growth rates of investment in $R \& D$, a shortage of financial and intellectual resources, ineffective legislation indicate the presence of problems of strategic management of the innovative development of Ukrainian regions and are the main factors inhibiting the innovative development of domestic enterprises. For Ukraine to enter the innovative path of development, in the 21 century the following areas of science should be the priority: applied mathematics and programming methodology, new energy, automation, pharmacology, integrated ecology, scientific and technological foundations of instrumentation, the theory of the development of a society based on knowledge, biology and genetic engineering, computer industry, informatisation, etc. (Sakulyeva, 2020; Kostygova et al., 2019; Ushakov \& Chich-Jen, 2018).

The theoretical significance of the article lies in the study of the essential and substantive characteristics of the strategic management of the innovative development of the region. The practical significance of the work is in proposing directions for improving the strategic management of the region's innovative development. The theoretical basis of the article is formed by fundamental developments on the topic under study, which were presented in the works of domestic and foreign authors.

Many authors have paid attention to the innovative development of regions. So, according to scientists, it is required to conduct a study of the features of managing the balanced development of regions in dynamics. Carrying out such research and analysis will make it possible to determine and develop the most effective management solutions for creating mechanisms for developing regional policy aimed at equalising objectively existing differences in the conditions of their functioning and at realising the advantages that individual regions have (Salikhova, 2008; Agafonova et al., 2020). At the same time, V. Reutov (2012) points out that improving state funding for structural and innovative shifts is possible through the creation, within the framework of the state budget, by analogy with the EU, but at the national level, of the National Structural Fund, the funds of which will be used to provide positive shifts in the structure of the economy in accordance with certain priorities of public investment with strict control over the directions and effectiveness of their use. Pidkaminniy and 
Tsipurinda (2011) note that external factors of influence and mechanisms of promoting innovative development of enterprises based on the implementation of economic and innovation policy by branches of government at all levels are: legal support; information support; organisational support; provision of the necessary space and premises; providing orders for the sale of products for local needs; providing protection to the internal market; promoting the development of economic infrastructure; improving the environmental safety of economic activities; economic (financial) support for the implementation of innovation policy; assistance in training and retraining of personnel; providing an opportunity for an enterprise to participate in the development and implementation of systemic urban regional development programs, a more flexible tax policy of the state. It should also be noted the need to use a program-targeted approach in the implementation of financing based on targeted programs for the development of an innovative cluster, which will help stimulate innovative growth and create scientific and technological profit centres, providing tax preferences to investors in knowledge-intensive breakthrough sectors of the Russian economy. A number of researchers share the opinion that the sustainable development of a country and its regions to a large extent depends on their position in the world economy, interaction with other states, including development in innovative areas and effective financing. So, O. Dotsenko (2012) argues that the financial mechanism of the region's innovative development is a combination of various forms, methods, types and elements of financial relations in the region aimed at innovative development in order to increase its socio-economic level and competitiveness. To ensure the effectiveness of such cooperation, a high degree of involvement of the participants in the innovation process and the presence of appropriate structures are required.

But in publications on this topic in recent years, actual trends, problems and prospects of strategic management of innovative development at the regional level have not been practically disclosed in relation to the Ukrainian Black Sea region, including the Odesa region. And this is exactly what is considered within the framework of the article.

\section{Literature Review}

In the past few decades, research in the field of strategic management at the state, regional, and micro-level has been increasing more and more. It is possible to characterize the main approaches of the authors to the understanding of strategic management. Thus, B. Ghimire (2020) points out that a strategy is a broad plan of action aimed at achieving the goals of an organization, it is a roadmap for the future. J. Bryson and B. George argue that strategic management is an approach to strategy development by civil society or other actors that integrates strategy development and implementation and usually includes strategic planning for strategy development, how strategies are implemented, and continuous strategic learning. Strategic management can help communities or other actors achieve important goals and create community value (Bryson \& George, 2020; Ushakov et al., 2017). According to P. Maijanen, knowledge of the basic ideas of strategic management and its evolution helps to understand the world of business much more than just analysing it from more specific positions - economics, finance, accounting or marketing. Strategic management integrates all the elements, determining how to achieve and maintain a competitive advantage (Maijanen, 2020). From the point of view of H. Aggerholm (2018), traditionally strategic management consists of three elements: strategic analysis, selection and implementation, and is a product of rational-analytical thinking.

It should be noted the role of strategic management in innovation management. Indeed, a strategic approach is an important component of the management of innovative development at any level of management. Many researchers recognise the importance of innovative development. P. Bubenko and O. Dymchenko (2020) believe that effective innovation policy in a certain economic sphere of activity should be based on the functional properties of the forms of spatial organisation of production, on the one hand, and the location of productive forces, on the other. E. Alfaro and co-authors point out that strategic management of innovation is associated with the use of appropriate strategic management techniques in order to increase the impact of innovation on productivity growth (Alfaro et al., 2019). 
In recent decades, new trends in the strategic management of regional development have been formed, the most significant of which is the need to link regional policy and regional development with the processes of globalisation and the transition to an innovative path of development. The role of innovation in regional development is high due to the fact that innovation directly affects the main indicators of regional development. And, in addition, they influence the structure of the regional economy, increase its competitiveness not only in the domestic but also in the international market, which ultimately has a beneficial effect on the quality of life of the population.

There are many studies of the features of strategic management of innovative development of the region. Some researchers believe that when choosing a strategy for the innovative development of a region, it is important to rely on the competitive advantages of the region and, especially, on the existing developments of high technologies (Vasilenko and Loktionova, 2018; Danilishin, 2009; Dunaieva et al., 2021). To ensure the innovative development of the economy of any region, innovations of organisational, economic and administrative (legal) content are used. V. Simonenko (2009) believes that it is necessary to radically change the role of science in the country, to ensure that the scientific potential of the country is necessary, first of all, in the domestic economy, so that the created innovative potential is not reduced to the mechanisms of a "virtual economy" that has little to do with the real production sector. In the modern strategic management of the innovative development of the region, the tools of strategic management are quite fully presented - strategies for innovative development, including in the context of a cluster, programs, projects. Investment instruments include loans, guarantees, financial leasing, issue of shares, etc. These instruments in relation to investments in science-intensive business projects should be supplemented by flexible financial schemes of state support at the federal and regional levels. The effectiveness of innovation in a region depends on the existing system of mechanisms for its innovative development. It can be argued that the mechanism of innovative development of the region includes organisational (organisation, development and implementation of innovations in the region), economic and financial (financing and incentives, insurance of innovations) approaches, methods and principles of formation of regional innovation policy and strategies that ensure the growth of competitiveness, an increase in the level of socio-economic development and the quality of life of the region's population (Kuletskiy et al., 2020; Mishchenko et al., 2021; Shtal et al., 2019).

The organisational mechanism should ensure the emergence of innovations, the financial mechanism should create conditions for financing innovative activities, and the economic mechanism should ensure the process of commercialisation of innovations and their further development. All types of the mechanism of innovative development are interconnected and allow ensuring an effective innovation process in the region. In addition, the mechanism of innovative development should be based on the interaction of business entities, state authorities and local governments, which have at their disposal financial, material, mineral, raw materials, intellectual and information resources for effective innovation in the region. At the same time, all subjects of innovation should have a certain degree of freedom with a combination of a high level of responsibility within the framework of certain regional development priorities. I. Lyakh believes that the formation of such a concept as "innovative mechanisms" at the national and regional levels in Ukraine began only in the 2000s, so it would be premature to assess their effectiveness. But the improvement of the existing ones, the development and implementation of modern mechanisms for managing innovative development at all levels of the national system will make it possible to form a balanced and adequate state policy in the field of innovations, which will help to increase the competitiveness of the state in the future (Lyakh, 2014).

The effectiveness of the functioning of the mechanism for the innovative development of the region depends on a reasonable choice of innovative projects in accordance with regional priorities, the availability of sources of financing, and obtaining optimal effects from their implementation. An effective mechanism for the innovative development of a region begins with effective organisational steps, which are the basis of the organisational mechanism (Rudenko, 2020; Shtal et al., 2018). First of all, this concerns the creation and maintenance of conditions for innovative development in the region by promoting the introduction of innovative technologies and the release of innovative products at 
the enterprises of the region; technology transfer formation; implementation of regional programs for training and retraining of personnel; assistance in the implementation of innovative projects by regional enterprises for the needs of public utilities; ensuring the economic security of the subjects of innovation in the region; assistance in organising and holding seminars and conferences on innovative and scientific and technical issues; monitoring innovation activities in the region; improving the tariff policy for enterprises and organisations of the region engaged in innovative activities; support and control of large innovative projects at the regional level. The interaction of state and local authorities, economic entities of the region in the formation of innovation policy involves the coordination of the activities of all authorities, regional centres on the economy, industrial policy, innovation and investment policy, scientific and technological development, as well as joint work with public organisations, industry trade unions (Naumenkova, 2015; Bezpalov, 2018a; Malova, 2020).

Information support for innovative development in the region is provided by creating an information infrastructure designed to ensure the dissemination of information about innovative products, projects in the region, as well as available sources of funding. The economic mechanism of innovative development of the region is responsible for the strategic management of the innovative development of the region and is associated with the development of goals, programs, projects, taking into account the current socio-economic state of the region, state policy for the development of innovations, the innovative and production potential of the region, external and internal factors and the needs of the region for innovation. The innovation development strategy is aimed at combining the scientific and technical potential of the region and investment policy, through which innovative products and technologies are created. The innovative development today is planned by drawing up long-term programs for the innovative development of the region, which are an integral part of the program for the socio-economic development of the region and the program of innovative development of Ukraine as a whole, and include a set of ways, rules, processes and tools aimed at achieving the set strategic innovative and socio-economic goals of the region and Ukraine. Innovation marketing is aimed at studying the market, promoting the development and regulation of sales markets for innovative products and services both within the region and beyond, as well as supporting the competitiveness of the region and enterprises (Bezpalov, 2018b; Rudenko, 2019).

The financial mechanism for the innovative development of a region is a combination of various forms, methods, types and elements of financial relations in the region, which are aimed at the innovative development of the region in order to increase its socio-economic level and competitiveness. Sources of financing for innovative development include own funds of enterprises, budget funds, foreign investments, venture capital, and credit resources.

\section{Materials and Methods}

The methods used in the research can be divided into qualitative and quantitative. Qualitative methods in this case are the analysis of the synthesis of scientific publications, as well as legal information that is related to the topic under study. For this, in particular, strategic documents are used that are related to the innovative development of the region (Development strategy of Odessa region..., 2020).

Quantitative methods are methods for analysing statistical information. The basis for this analysis is statistical data obtained in the statistical database of the Main Department of Statistics for the Odesa region. To analyse the indicators characterising the innovative development of the region, the author selected the following indicators: dynamics of certain types and total costs of research and development by type of work in the Odesa region; dynamics of the specific weight of certain types of expenses for scientific research and development by type of work; dynamics of the share of enterprises engaged in innovation in Odesa, Mykolaiv and Kherson regions;

- the dynamics of spending on innovation at industrial enterprises in Odesa, Mykolaiv and Kherson regions; dynamics of the number of introduced new technological processes in Odesa, Mykolaiv and Kherson regions; dynamics of the number of employees involved in scientific research 
and development in the Odesa region; dynamics of the number of certain categories of workers involved in the implementation of research and development in the Odesa region (researchers, technicians, assistant personnel); dynamics of the number of employees involved in the implementation of research and development with a scientific degree; dynamics of the share of certain categories of workers involved in the implementation of scientific research and development in the total number of researchers (doctors of sciences, doctors of philosophy). At the same time, to analyse individual indicators, it is necessary to study data for several years, and compare individual indicators with those of neighbouring regions.

It is important to characterise the Odesa region. This region of Ukraine is the largest in terms of area; it occupies the territory of the North-Western Black Sea region from the mouth of the Danube to the Tiligul estuary and stretches from the sea to the north, inland for 200-250 km. It includes 26 administrative districts, 19 cities, 32 united territorial communities, 33 villages and 1123 rural settlements. The administrative centre of the region is the city of Odesa - one of the largest cities in Ukraine, an important transport, industrial, scientific, cultural and resort centre with a population of 1013.4 thousand people.

Research stages:

- analysis of the dynamics and structure of expenses for scientific research and development in the Odesa region;

- analysis of the participation of enterprises of the Odesa region in innovative activities, including comparison with neighbouring regions;

- analysis of the implementation of innovations at the enterprises of the Odesa region, including comparison with neighbouring regions;

- analysis of the personnel potential of the region's innovative development.

\section{Results and Discussion}

First, it is necessary to conduct a study of the costs of performing research and development by type of work in the Odesa region in 2015-2019 (Table 1).

Table 1 Dynamics of expenses for scientific research and development by type of work in the Odesa region in 2015-2019, thousand UAH

\begin{tabular}{|l|}
\hline Indicator \\
\hline Total expenses on research and development \\
\hline The number of expenses for the implementation of fundamental scientific research \\
\hline The number of expenses for the implementation of applied scientific research \\
\hline The number of expenses for the implementation of scientific and technical (experimental) developments \\
\hline Source: Main Department of Statistics in Odesa region
\end{tabular}

From the data in Table 1, it follows that the total cost of innovative development in the Odesa region has grown significantly in 2015-2019 by UAH 140472.2 thousand, while there was an increase in all types of expenses for scientific research and development: the number of expenses for performing fundamental scientific research increased by UAH 19507.9 thousand, the number of expenses for performing applied scientific research increased by 71341.7 thousand $\mathrm{UAH}$, the number of expenses for the implementation of scientific and technical (experimental) developments increased by 49622.6 thousand UAH. Further, the share of each type of expenses on research and development by type of work in the Odesa region in 2015-2019 is analysed, which is shown in Figure 1. 
Figure 1 Dynamics of the share of certain types of expenses for scientific research and development by type of work in the Odesa region in $2015-2019, \%$

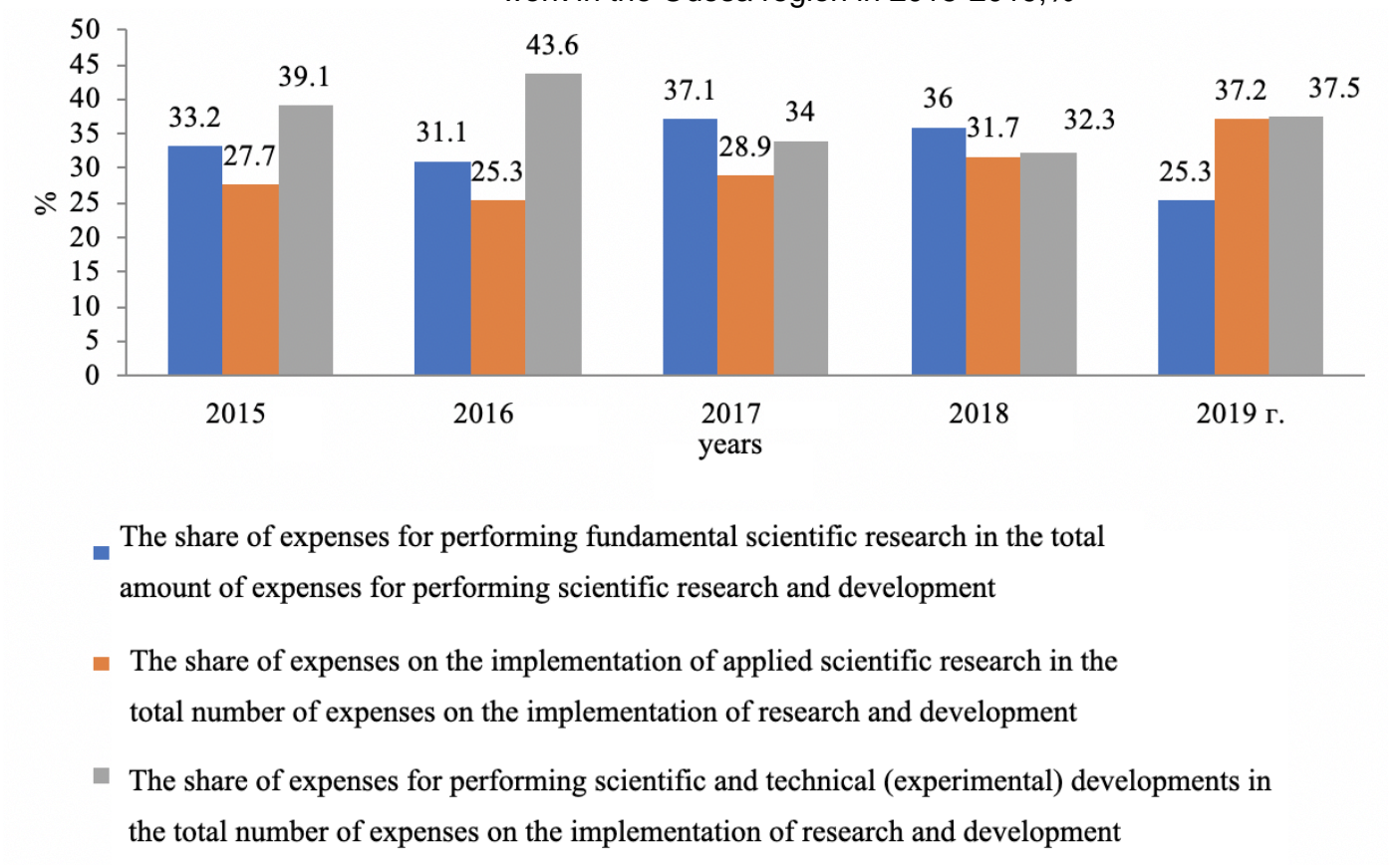

Source: Main Department of Statistics in Odesa region

As can be seen from the data in Figure 1, the share of expenditures for scientific research and development by type of work in the Odesa region for 2015-2019 changed slightly. In 2019, compared to 2015 , the share of expenses for performing fundamental scientific research in the total number of expenses for performing scientific research and development decreased by $7.9 \%$; the share of expenses for performing scientific and technical (experimental) developments in the total number of expenses decreased on the implementation of research and development by $1.6 \%$, the share of expenses on the implementation of applied scientific research in the total number of expenses on the implementation of research and development increased by $9.5 \%$. For a more comprehensive characterisation of the innovative development of the Odesa region, special attention should be paid to comparing individual indicators with other nearby regions of the country. Figure 2 examines the dynamics of the share of enterprises engaged in innovations in the Odesa, Mykolaiv and Kherson regions in 2015-2019.

Figure 2 Dynamics of the share of enterprises engaged in innovations in Odesa, Mykolaiv and Kherson regions in 2015-2019,\%

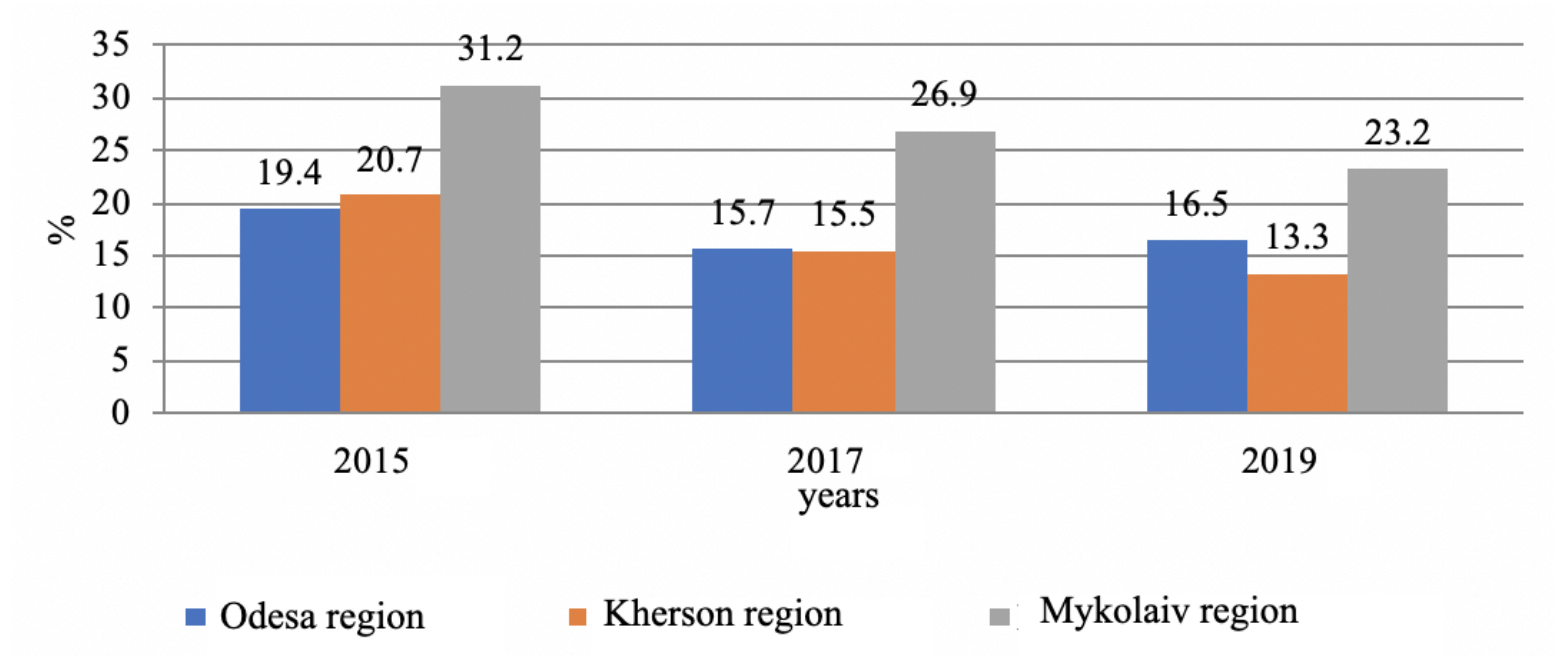

Source: Main Department of Statistics in Odesa region, Main Department of Statistics in Kherson region, Main Department of Statistics in the Mykolaiv region 
Figure 2 shows that the Odesa region does not have the highest indicators, since it is significantly ahead of the Mykolaiv region. At the same time, in developed countries, innovation is one of the most important directions of the country's development. The number of innovatively active industrial enterprises in these countries reaches $70-80 \%$, while in Ukraine this indicator is constantly decreasing. When analysing statistical data, it was revealed that in the Odesa region the share of enterprises engaged in innovations is average compared to neighbouring regions. In all considered areas for 20152019 there is an annual decline in the share of innovatively active enterprises: in the Odesa region the overall decline was $2.9 \mathrm{pp}$, in the Kherson region - $7.4 \mathrm{pp}$, in the Mykolaiv region - $8 \mathrm{pp}$. Based on the data presented, it can be concluded that a number of innovatively active enterprises are transferred to a group that is not engaged in innovative activities or even liquidated. Figure 3 shows a comparison of the dynamics of spending on innovation at industrial enterprises in the Black Sea region (Figure 3).

Figure 3 Dynamics of spending on innovations at industrial enterprises in Odesa, Mykolaiv and Kherson regions in 2015-2019, thousand UAH

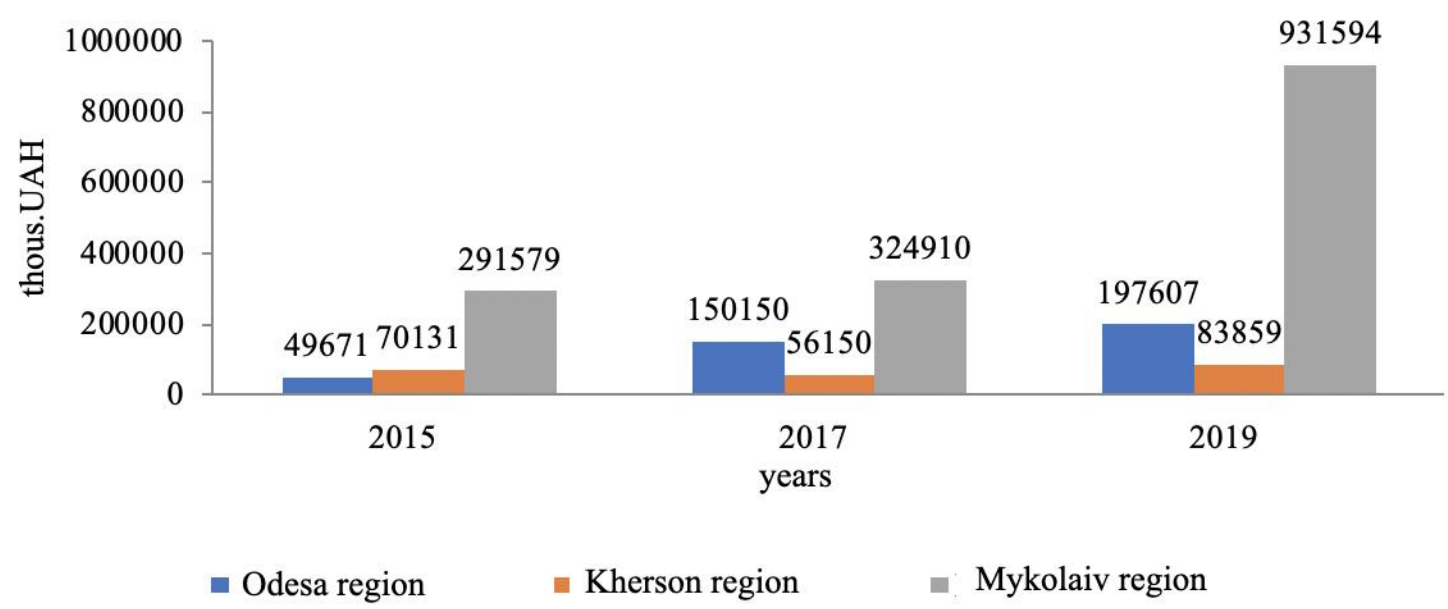

Source: Main Department of Statistics in Odesa region, Main Department of Statistics in Kherson region, Main Department of Statistics in the Mykolaiv region

From the data presented in the diagram in Figure 3, it can be concluded that there are positive changes in the innovation sphere in the analysed regions of Ukraine, since in 2019, relative to 2015, expenses on innovation activities increased. The greatest value and the greatest growth was recorded in the Mykolaiv region, the smallest - in the Kherson region. The cost of innovation in the Mykolaiv region is almost 5 times higher than in the Odesa region, although the population of the Mykolaiv region is 2 times less than in the Odesa region. Figure 4 shows the dynamics of the number of introduced new technological processes in Odesa, Mykolaiv and Kherson regions in 2015-2019.

As can be seen from the data in Figure 4, the number of introduced new technological processes in the Odesa region increased annually: in 2015, 26 new technological processes were introduced, in 2018 their number increased by 24, and in 2019 by another 1 . In the Kherson region, this indicator decreases annually - for 2015-2019 the decrease was 12 units. In the Mykolaiv region in 2017 there was an increase in the number of introduced new technological processes, and in 2019 - a decrease. Of the regions under consideration, the Odesa region has the highest value of the number of introduced new technological processes and the best dynamics. Next, the development of human resources for innovative development of the Odesa region is considered. Figure 5 shows the dynamics of the number of employees involved in research and development in 2015-2019 in the Odesa region. 
Figure 4. Dynamics of the number of introduced new technological processes in Odesa, Mykolaiv and Kherson

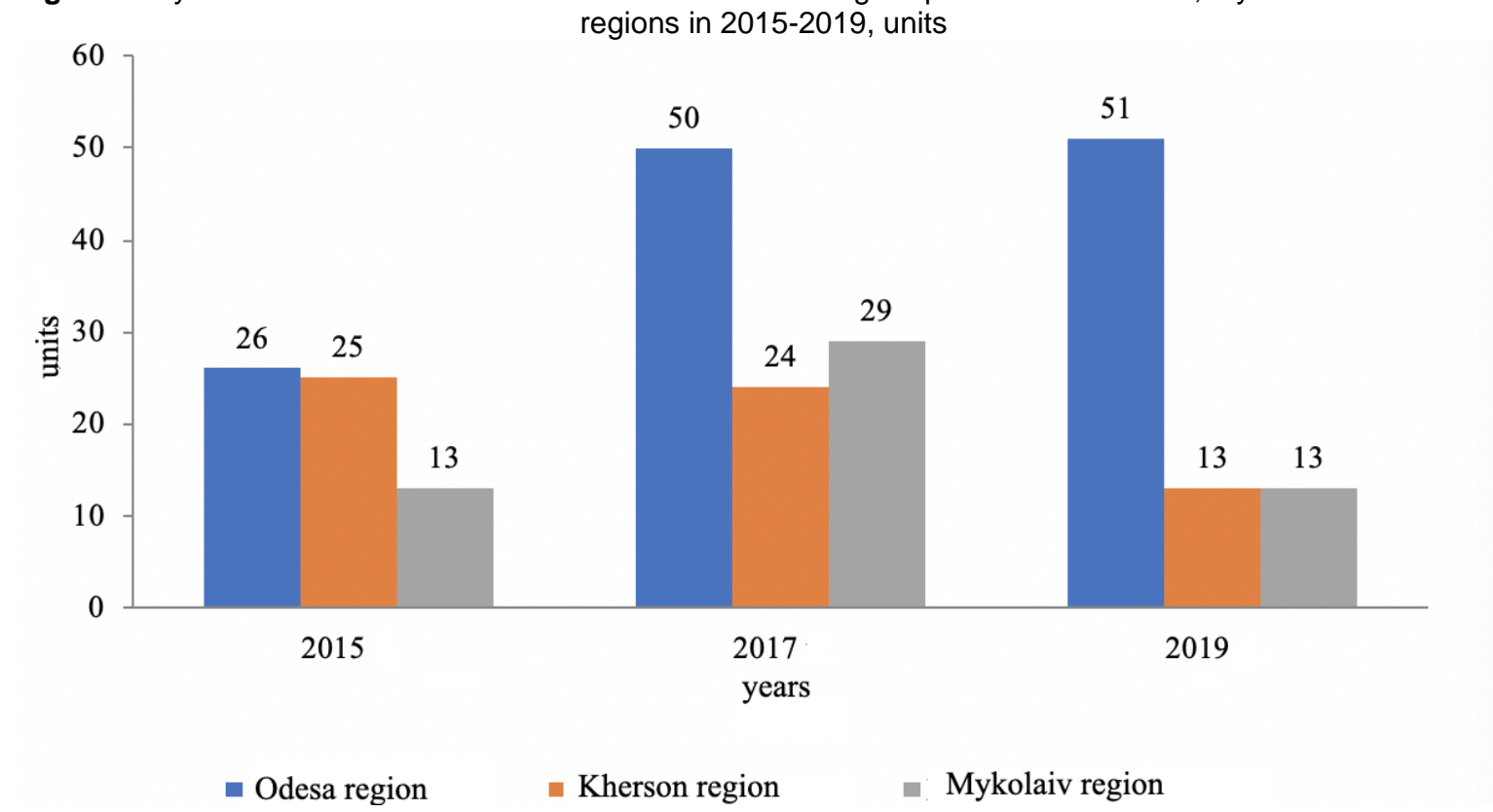

Source: Main Department of Statistics in Odesa region, Main Department of Statistics in Kherson region, Main Department of Statistics in the Mykolaiv region

Figure 5 Dynamics of the number of employees involved in research and development in the Odesa region in

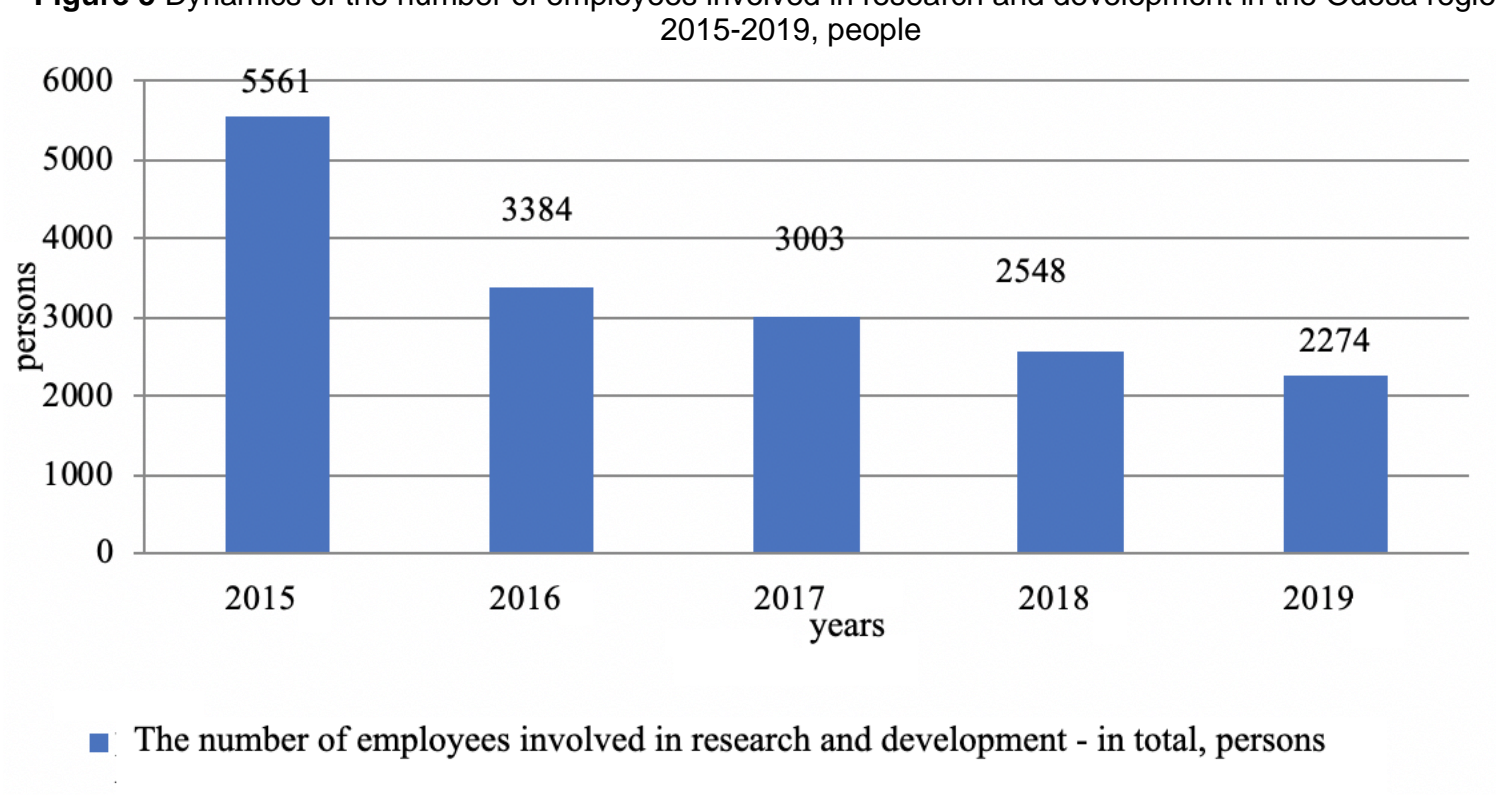

Source: Main Department of Statistics in Odesa region

As can be seen from the data presented in Figure 5, in 2015-2019 in the Odesa region, there was an annual decrease in the number of employees involved in the implementation of scientific research and development. The total decrease in four years amounted to 3287 people, which significantly negatively characterises the development of human resources for the innovative development of the region. Further, Figure 6 shows the dynamics of certain categories of workers involved in the implementation of scientific research and development in the Odesa region in 2015-2019. 
Figure 6 Dynamics of the number of certain categories of workers involved in research and development in the Odesa region in 2015-2019, people

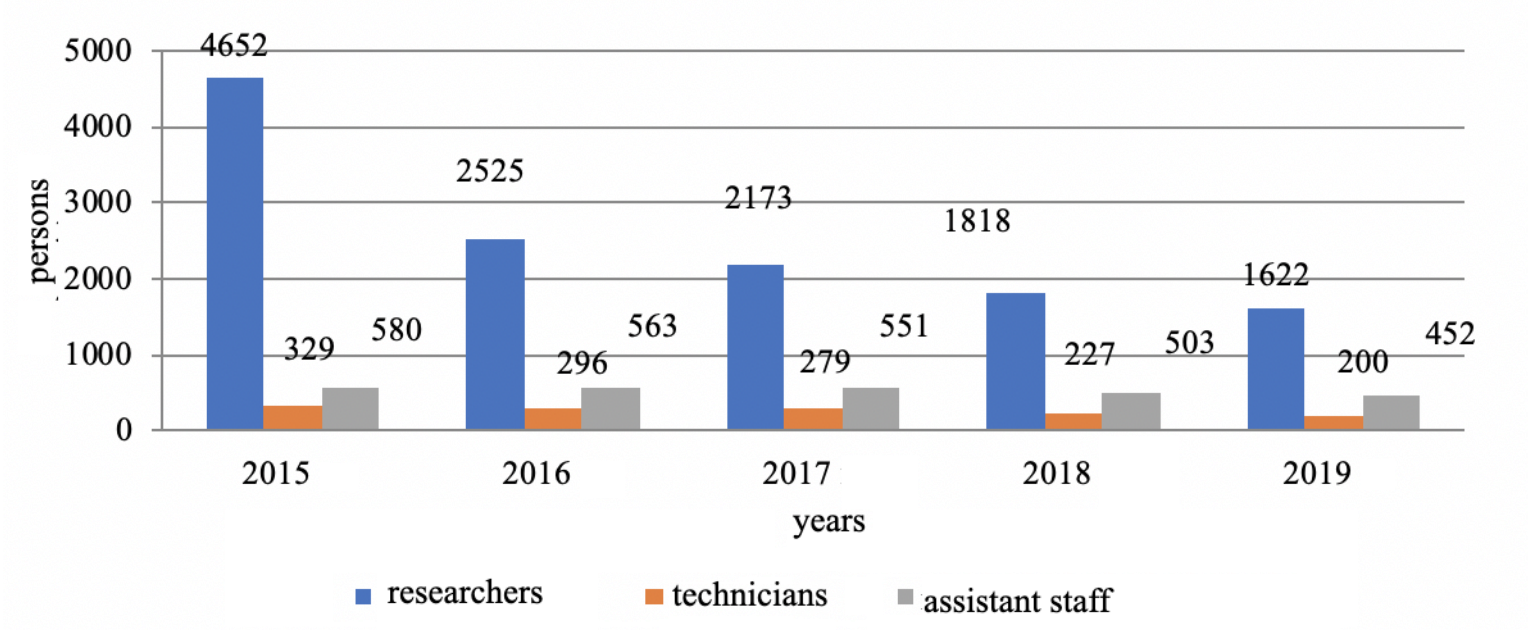

Source: Main Department of Statistics in Odesa region

As can be seen from the diagram in Figure 6, the reduction in the number is observed in all categories of personnel, which also negatively characterises the human potential of the region's innovative development. The decline in the number of researchers significantly affected the number of researchers - their number decreased by 3030 people from 4652 people in 2015 to 1622 people in 2019, the number of technicians decreased by 129 people from 329 people in 2015 to 200 people in 2019, the number of technicians personnel - for 128 people from 580 people in 2015 to 452 people in 2019. Of the total number of employees involved in research and development, most (71-83\%) during 2015-2019 in the Odesa region were researchers. Figure 7 shows the change in the number of employees involved in research and development with a scientific degree in 2015-2019 in the Odesa region.

Figure 7 Dynamics of the number of employees involved in the implementation of research and development with a scientific degree in the Odesa region in 2015-2019, persons

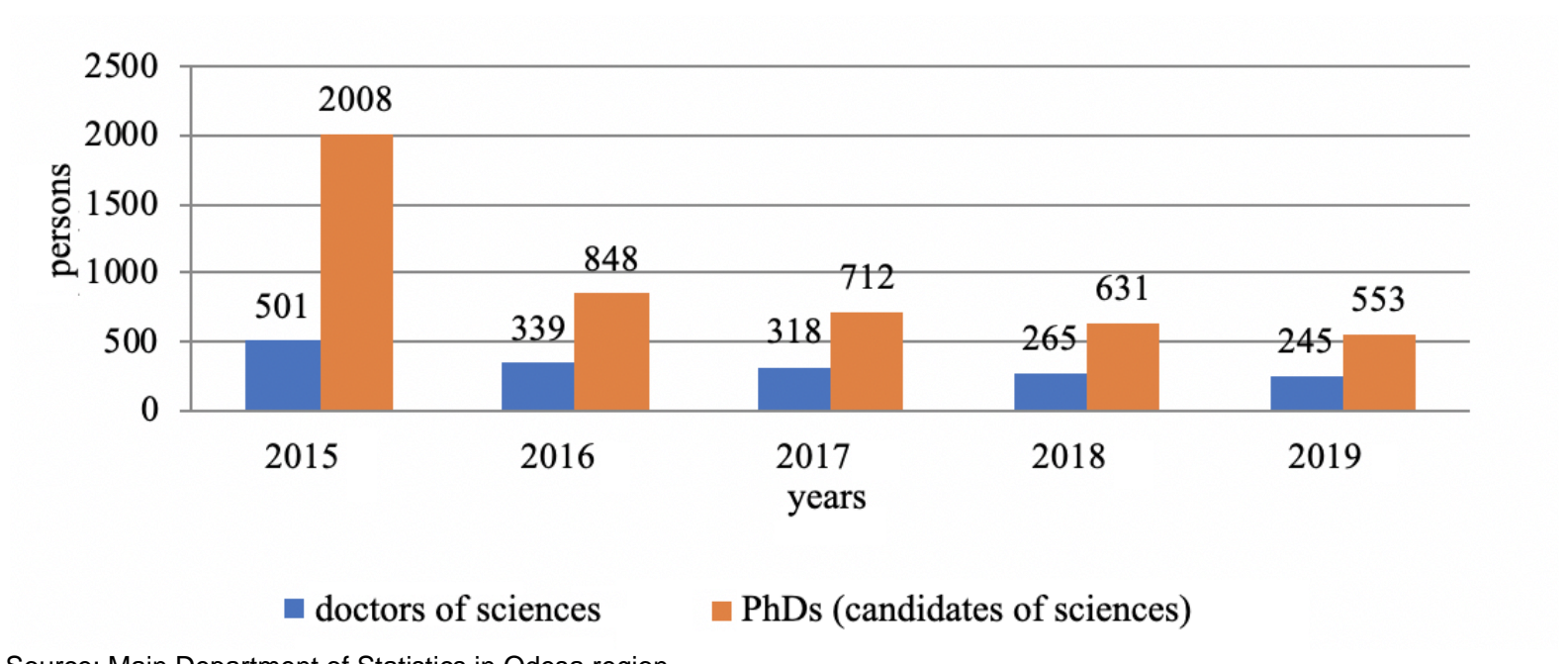

Source: Main Department of Statistics in Odesa region

From the data in Figure 7, a negative trend can be noted: for 2015-2019 in the Odesa region there was a decrease in the number of doctors of sciences by 256 people from 501 people in 2015 to 245 people in 2019, the number of candidates of sciences decreased by 1455 people from 2008 people in 2015 to 553 people in 2019. Figure 8 presents the share of certain categories of workers involved in the implementation of research and development in the total number of employees in the Odesa region in 2015-2019. 
Figure 8 Dynamics of the share of certain categories of workers involved in the implementation of research and development in the total number of scientific workers in the Odesa region in 2015-2019,\%

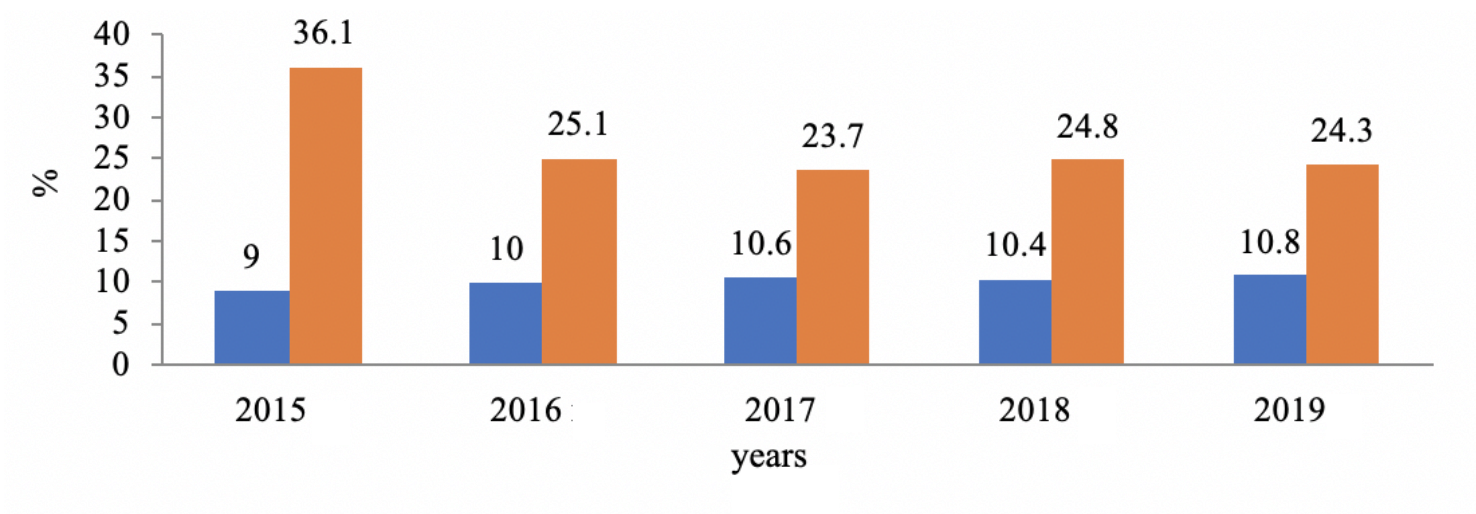

- The share of doctors of sciences in the total number of employees involved in research and development

The share of $\mathrm{PhDs}$ in total the number of employees involved in research and development

Source: Main Department of Statistics in Odesa region

The data in Figure 8 allow concluding that for the period 2015-2019 the share of doctors of sciences in the total number of employees involved in research and development increased by 1.8 p.p., from $9 \%$ in 2015 to $10.8 \%$ in 2019, and the share of PhDs in total the number of employees involved in research and development decreased by 11.8 percentage points from $36.1 \%$ in 2015 to $24.38 \%$ in 2019 . At the same time, understanding the importance of effective management of regional development, the authorities of the Odesa region in every possible way contribute to the process of introducing the best world practices in the activities of regional authorities, which can contribute to the activation of innovation policy for the development of the region. In the regions of Ukraine (including the Odesa region), there are strategies for socio-economic development, which include sections, activities and operational goals to strengthen innovation potential. That is, in the regions, there is no single approach to defining the conceptual provisions of innovative development. Based on the Strategy for the Development of the Odesa Region for the period 2021-2027, regional development planning for the medium term was conducted, which is the result of the work of various subjects of regional development in the region: the regional council, the regional state administration, representatives of associations of entrepreneurs, the public and scientists, is the basis for regional and local development programs (Development strategy of Odessa region..., 2020). The main directions of the regional policy of the Odesa region in the field of innovation are: improving the organisational and legal environment for the implementation of innovative activities, the creation of a comprehensive support system for innovative activities at all stages of its implementation at the national and regional levels, the development of innovation and investment infrastructure. Restraining the innovation activity of industrial enterprises in Ukraine is explained, first of all, by the limited sources of its financing, which is associated with the financial and economic instability in the state and the crisis of most enterprises, the lack of own funds from enterprises to finance innovation, high credit rates and the inability to obtain long-term loans, insufficient using indirect measures to stimulate innovation. After analysing the strategic management of innovative development of the Odesa region, a number of conclusions can be drawn. It was noted that the Odesa region is inferior to one of the nearby regions - the Mykolaiv region in terms of the share of enterprises engaged in innovations and in terms of spending on innovations. But the Odesa region is leading in comparison with the nearby regions (Mykolaiv and Kherson regions) in the number of new technological processes introduced at industrial enterprises. In addition, a positive factor is that in recent years in the region, the costs of research and development have been growing, and the number of new technological processes introduced is growing. 
Negative tendencies of changes in the personnel potential of the innovative development of the region were noted. So, for 2015-2019 in the Odesa region, there was a reduction in the number of all categories of personnel involved in the implementation of research and development. In addition, the share of the number of doctors of philosophy in the total number of employees involved in research and development decreased by 11.8 percentage points from $36.1 \%$ in 2015 to $24.38 \%$ in 2019 . But as a positive factor, it was noted that for the period 2015-2019 the share of doctors of sciences in the total number of employees involved in research and development increased by 1.8 p.p., from $9 \%$ in 2015 to $10.8 \%$ in 2019. The data revealed insufficient efficiency of the innovative development of the Odesa region, although the indicators of innovative activity have positive trends. The positive dynamics of innovative development can be explained by the measures taken by the state and regional authorities in the financial and organisational spheres. But in comparison with developed countries, the level of innovation development in the studied region is low. At the same time, an important positive factor in the management of the innovative development of the region is the fact that the Strategy for the Development of the Odesa Region for the period 2021-2027 has been developed, which sets tasks and measures for the near future for the innovative development of the region.

Various authors express several points of view regarding the innovative development of regions. $\mathrm{E}$. Tkhakushinov (2016) believes that regional authorities in the implementation of the strategy, given the limited economic and financial base, should not so much directly participate in the functioning of individual enterprises, but rather create stimulating conditions for the development of priority processes from the standpoint of the local community. I. Lytvyn (2020) believes that the authorities should improve the business climate, increase the country's investment attractiveness, and develop a competitive environment. Thanks to such a strategy, it will be possible to ensure a significant inflow of private investment, ease the burden on public finances, create demand for innovation, and stimulate the transformation of the economy into an innovative one (Lytvyn, 2020). According to the author, the tools for strategic management of the region's innovative development should be constantly improved taking into account the experience of developed countries. Particular attention should be paid to stimulating the innovative activity of business and creating conditions for the formation and updating of the competencies of the innovative activity of the population. It is necessary to create such structures as business incubators and technology parks, systems of centres for youth innovative creativity.

Thus, the Odesa region has the resources and opportunities to improve the tools for strategic management of innovative development, for the growth of innovative activity in the near future. This requires the active participation of all government authorities and business representatives in the development and implementation of effective strategic management tools for the efficient use of all available resources. Currently, some of the measures for the innovative development of the Odesa region can be considered effective, but the measures taken are not enough, since the level of the region is still significantly behind the level of implementation of innovations in developed countries.

\section{Conclusions}

Innovative activity in Ukraine and its regions requires the creation of effective and efficient tools for the strategic management of innovative development. Strategies, programs and projects act as instruments for the innovative development of regions, participation in which, on the one hand, increases the innovative activity of a business, on the other hand, stimulates the formation and development of competencies in the innovative activity of the population. Analysis of the innovative development of the Odesa region revealed both positive and negative trends. The positive aspects include the following: Odesa region is leading in comparison with neighbouring regions (Mykolaiv and Kherson regions) in terms of the number of new technological processes introduced at industrial enterprises, in recent years, the region has been spending more on research and development, and the number of new technological processes introduced is growing, the Development Strategy of the Odesa region for the period 2021-2027 was developed, in which tasks were set and measures were developed for the near future for the innovative development of the region, in 2015-2019 in the 
region, the proportion of $\mathrm{PhDs}$ in total research and development workforce has grown. To improve strategic management in the region, it is necessary to stimulate and support innovative activities through direct organisational incentives for enterprises to form and implement innovative development programs; to provide, on a competitive basis, grants to enterprises in priority areas of their innovative activities; to support the development of in-house science, including by providing companies with access to unique research equipment, testing and certification services for fundamentally new products; to improve the instruments of tax incentives for innovative activities of enterprises; to strengthen the innovative orientation of the activities of specialised banks and financial development institutions; to improve the support systems for the export of high-tech products (services); to introduce mechanisms to support the import of certain advanced foreign technologies characterising by a high potential for distribution in the economy.

\section{References}

1. Agafonova, I.I., Sidorova, E.Y., Polezharova, L.V., Ryakhovsky, D.I., \& Kostina, O.V. (2020). Certain measures for tax regulation of industrial development and digital trade in Russia (National and international aspects). Journal of Advanced Research in Dynamical and Control Systems, 12(3 Special Issue), 1214-22.

2. Aggerholm, H. (2018). Strategic Management. https://onlinelibrary.wiley.com/doi/abs/10.1002/9781119010722.iesc0176 [Accessed February 25, 2021].

3. Alfaro, E., Fei, Yu., Rehman, N., Eglantina, H., \& Kabeya, P. (2019). Strategic management of innovation.

https://www.taylorfrancis.com/books/e/9781315276670/chapters/10.4324/9781315276670-7 [Accessed February 25, 2021].

4. Bezpalov, V.V. (2018a). Development of a methodology for managing foreign trade activities in the industrial complex of the region under conditions of import substitution. Ekonomika $i$ Predprinimatelstvo, 1(90), 353-9.

5. Bezpalov, V.V. (2018b). Vneshnetorgovaya deyatelnost promyshlennykh kompleksov i yeye rol v formirovanii imidzha gosudarstva. Upravleniye Ekonomicheskimi Sistemami: Elektronnyy Nauchnyy Zhurnal, 9(115), 22.

6. Bobrova, A.V., Stepanov, E.A., Sakulyeva, T., Zhumabekova, G.Z., \& Yesturliyeva, A.I. (2020). The influence of alternative fuels on the development of large-scale production. Journal of Environmental Accounting and Management, 8(4), 335-49.

7. Bryson, J., \& George, B. (2019). Strategic Management in Public Administration. Oxford: Oxford University Press.

8. Bubenko, T., \& Dymchenko, O. (2020). The Territorial Organization for Innovative Development. Business Inform, 6, 109-15.

9. Danilishin, B. (2009). Social priorities of economic development. Economy. Management. Innovations. Series: Economic Sciences, 1, 43-52.

10.Development strategy of Odessa region for the period 2021-2027. 2020. https://www.minregion.gov.ua/wp-content/uploads/2020/05/strategiya-rozvytku-odeskoyioblasti-na-period-2021-2027-roky.pdf. [Accessed February 25, 2021].

11.Dotsenko, O. (2012). The mechanism of innovative development of the region. Economic Bulletin of the National Mining University, 3, 31-40.

12.Dunaieva, I., Barbotkina, E., Vecherkov, V., Popovych, V., Pashtetsky, V., Terleev, V., Nikonorov, A., \& Akimov, L. (2021). Spatial and temporal databases for decision making and forecasting. Advances in Intelligent Systems and Computing, 1259, 198-205.

13.Ghimire B. (2020). Strategic Management. 
https://www.researchgate.net/publication/340816205_Strategic_Management.

[Accessed February 20, 2021].

14.Gurianov, P. (2015). Dividend policy and major shareholding profitability. Metallurgical and Mining Industry, 7(7), 101-6.

15.Gurieva, S.D., Zashchirinskaia, O.V., \& Udavikhina, U.A. (2019). Creation of Coping-Profiles of managers for obtaining methods of coping in socially significant situations during negotiations. Journal of Intellectual Disability - Diagnosis and Treatment, 7(3), 179-87.

16.Kostygova, L., Sidorova, E., \& Vikhrova, N. (2019). Modern clusters and assessment of their innovative development. Entrepreneurship and Sustainability Issues, 7(1), 603-14.

17.Kuletskiy, K.V., Zhunda, S.V., Rudakov, M.L., Pasynkov, A.V., \& Sobyanin, D.S. (2020). Use of occupational risk management procedure with the aim of improving training on occupational safety for the employees of the open-pit coal mining organizations. Bezopasnost' Truda $v$ Promyshlennosti, 2020(2), 74-9.

18.Lyakh, I. (2014). Methodical approach to a comprehensive assessment of innovative development of the region. Economic Bulletin of Donbass. 2 (36), 169-78.

19. Lytvyn, I. (2020). Innovative development of the region, as the most important factor of sustainable development (on the example of the Republic of Tatarstan). Collection on the results of the AllRussian scientific-practical conference "Business Strategies and their internationalisation". Proceedings of the All-Russian scientific-practical conference. Moscow: Financial University, p. 154157.

20.Maijanen, P. (2020). Teaching the history of strategic management. Cheltenham: Edward Elgar Publishing.

21.Main Department of Statistics in Kherson region. http://www.ks.ukrstat.gov.ua [Accessed February 25, 2021].

22. Main Department of Statistics in Odesa region. http://od.ukrstat.gov.ua [Accessed February 25, 2021].

23. Main Department of Statistics in the Mykolaiv region. http://mk.ukrstat.gov.ua [Accessed February 25, 2021].

24.Malova, T.A. (2020). What signal paradoxes of global economy. Vestnik Mgimo Universiteta, 13(3), 225-42.

25.Mishchenko, S., Naumenkova, S., Mishchenko, V., \& Dorofeiev, D. (2021). Innovation risk management in financial institutions. Investment Management and Financial Innovations, 18(1), 191-203.

26. Naumenkova, S.V. (2015). Financial inclusivity: Economic contents and the approaches to its assessment. Actual Problems of Economics, 166(4), 363-71.

27.Pidkaminniy, I., \& Tsipurinda, V. (2011). Systemic factors influencing the innovative development of the enterprise. Effective economy, $3 \mathrm{http}: / / w w w . e c o n o m y \cdot n a y k a . c o m . u a / ? o p=1 \& z=480$ [Accessed February 25, 2021].

28.Reutov, V. 2012. Innovative development of the regional economic system of Ukraine in globalisation conditions. Economics, 8, 4-8.

29.Rudenko, M.N. (2019). Institutional arrangements for the realization of regional entrepreneurial potential. Public Policy and Administration, 18(2), 209-24.

30.Rudenko, M.N. (2020). Development of a sustainable mechanism for the economic security of the region. Rivista di Studi sulla Sostenibilita, 2020(2), 33-47.

31.Sakulyeva, T. (2020). Towards the development of innovative technologies for the "mobility as a Service" system. Journal of Physics: Conference Series, 1515(3), 032003.

32.Salikhova, O. (2008). High technologies: definition and evaluation: [monograph], NAS of Ukraine. Kyiv: Information Analytical Agency, 290.

33.Shelygov, A.V., Filonova, A.S., \& Gorlova, O.E. (2019). Basic models of managing organizational changes in modern companies. Ekonomika i Predprinimatelstvo, 5(106), 1297-1302. 
34.Shtal, T.V., Lytovchenko, I., \& Poliakova, H.A. (2019). Development of professional competency of managerial staff on the basis of acmeological approach. Journal of Advanced Research in Law and Economics, 9(4), 1481-8.

35.Shtal, T.V., Polyakova, Y.O., Proskurnina, N.V., Dobroskok, I.B., \& Kot, O.V. (2018). Modeling of convergence of the economic system of Ukraine with g20 countries based on the analysis of structural changes in Ukrainian foreign trade. Journal of Advanced Research in Law and Economics, 9(6), 2129-45.

36.Simonenko, V. (2009). Formation of an innovative model of economic development of Ukraine: problems of the central government and regions. Regional Economy, 3, 7-15.

37.Tkhakushinov, E. (2016). Functions and mechanisms of strategic planning of regional development. International journal of applied and fundamental research, 12-5, 889-91.

38.Ushakov, D., \& Chich-Jen, S. (2018). Global economy urbanization and urban economy globalization: Forms, factors, results. E-Planning and Collaboration: Concepts, Methodologies, Tools, and Applications, 2-3, 1096-119.

39.Ushakov, D., Elokhova, I., \& Kharchenko, I. (2017). Tax instruments in public regulation of population employment: The factors of today's efficiency. International Journal of Ecological Economics and Statistics, 38(2), 161-8.

40.Vasilenko, V., \& Loktionova, O. (2018). Innovative component of strategic management of foreign economic activity of the enterprise. Bulletin of the National Technical University "Kharkiv Polytechnic Institute", 47, 42-7. 